Editorial

\title{
Econometrics Best Paper Award 2016
}

\section{Kerry Patterson}

Editor-in-Chief of Econometrics, Department of Economics, the University of Reading, Whiteknights, PO Box 217, READING, Berkshire, RG6 6AH, UK; k.d.patterson@reading.ac.uk; Tel.: +44(0)-118-378-8159

Received: 27 July 2016; Accepted: 27 July 2016; Published: 1 August 2016

Econometrics has had a distinguished start publishing over 92 articles since 2013, with 76,475 downloads. To mark the quality of the published articles I am pleased to announce the inauguration of the annual Econometrics award for the best article of the year, starting with articles published in 2015; the award carries a prize of 500 CHF.

The best article was judged by a distinguished panel of econometricians forming the Econometrics Award Advisory Board and comprised members of the Editorial Board of Econometrics and econometricians renowned for the extent and quality of their contributions and international experience.

The criteria for judgement were: originality of method, impact and longevity of contribution, clarity of exposition, and comparability of quality and contribution relative to major journals in the field, such as The Journal of Econometrics and The Journal of Business and Economic Statistics.

I am pleased to announce that the Best Paper Award 2016 has been awarded to:

Bent Nielsen (Nuffield College, Oxford) and Andrew Whitby (the World Bank), for their article entitled:

A Joint Chow Test for Structural Instability, Econometrics, 2015, 3, pp. 156-186.

Available online at: http:/ /www.mdpi.com/2225-1146/3/1/156

The authors develop the widely used Chow test in two important ways. The first is to show that the assumption of exogenous regressors can be relaxed to allow lagged dependent variables and deterministic terms. This is an important theoretical and practical development as it justifies the use of the Chow test for the widely estimated class of autoregressive distributed lag models, which consider a single equation as part of a vector autoregressive model. A typical use of the Chow test is in its one-step ahead, or pointwise, form as part of a diagnostic for a structural break at an unknown time. In the second important contribution, the authors develop a Supremum version of the pointwise test, which can be applied to detect parameter change or an outlier at an unknown breakpoint and is applicable for processes that are stationary, unit root or explosive.

Overall, the article sets a standard of excellence on all of the criteria required for a distinguished contribution to econometrics. There was an excellent development of theory, supported by simulations and a relevant application; moreover the exposition demonstrated the very best in clarity and structure. This winning article is likely to be widely cited and of considerable use to applied researchers, becoming part of the standard "toolkit" of econometricians.

\section{Econometrics Award Advisory Board}

Editorial Board Members:

Tomoriho Ando

Melbourne Business School, University of Melbourne, 200 Leicester Street, Carlton 3053, Australia

Steve Cook

Department of Finance, Swansea University, SA1 8EN, UK 


\section{Christian Kleiber}

Faculty of Business and Economics, Quantitative Methods Unit, Universität Basel, Peter Merian-Weg 6, 4002 Basel, Switzerland

\section{Carlos Lamarche}

Department of Economics, University of Kentucky, Gatton College of Business and Economics, Lexington, KY 40506-0034, USA

\section{Tommaso Proietti}

Dipartimento di Economia e Finanza, Università di Roma “Tor Vergata”

External Board Members:

In Choi

Department of Economics, Sogang University, 35 Baekbeom-ro, Mapo-gu Seoul, 121-742, Korea

Michael P. Clements

ICMA Centre, Henley Business School, University of Reading, UK

\section{Niels Haldrup}

Department of Economics and Business Economics, Aarhus University, Denmark

\section{LungFei Lee}

Department of Economics, the Ohio State University, USA

Acknowledgments: I would like to thank the members of the Econometrics Award Advisory Board for their invaluable support and contributions to the process of evaluating the shortlisted articles.

(C) 2016 by the author; licensee MDPI, Basel, Switzerland.This article is an open access article distributed under the terms and conditions of the Creative Commons Attribution (CC-BY) license (http:/ / creativecommons.org/licenses/by/4.0/). 